\title{
CLONACIÓN DE EMBRIONES Y DIGNIDAD HUMANA ${ }^{1}$
}

\author{
Angela Aparisi Miralles \\ Directora del Instituto de Derechos Humanos \\ Universidad de Navarra
}

Sumario:

I. Introducción. II. Bases biológicas de las técnicas de clonación. III. Aproximación a la noción de dignidad humana. IV. Dignidad y clonación de embriones humanos. V. El derecho a la libertad de investigación VI. La clonación de embriones frente al Derecho. VII. Conclusión.

\section{Introducción}

Durante los últimos años, los avances que se han producido en la denominada "nueva genética" ${ }^{2}$ han sido espectaculares. Con razón puede hablarse de una "nueva revolución", de consecuencias insospechadas. Es indiscutible que estos descubrimientos ofrecen grandes posibilidades en el campo biomédico. Pero es claro que también se plantean situaciones en las que la dignidad inherente a todo ser humano se puede ver amenazada. Ello pone de manifiesto la necesidad de que el jurista profundice, desde un conocimiento científico serio, en las consecuencias que estas nuevas técnicas van a tener para el hombre y su entorno. Se impone la necesidad de una reflexión serena que aborde aspectos científicos, éticos y jurídicos.

En relación con el nivel científico, quiero insistir en la idea de que los datos que aporta la genética no pueden ser algo totalmente ajeno al jurista. Por el contrario, es importante que el operador jurídico los conozca, al menos en sus formulaciones básicas, ya que cada vez es más clara la intervención del Derecho en estos temas. Un claro ejemplo de ello es la inclusión, en el nuevo Código Penal español, de un Título con el rótulo de "Delitos relativos a la manipulación genética".

\footnotetext{
'El texto del presente artículo es una versión ampliada y actualizada del artículo "Clonación terapéutica de embriones humanos. Aproximación é tico-jurídica", publicado en el Libro Homenaje a D. Antonio HERNÁNDEZ GIL, Vol. III, Editorial Centro de Estudios Ramón Areces, Madrid, 2001, pág. 2251-2271

${ }^{2}$ El nacimiento de lo que, en palabras del premio Nobel, Daniel Nathans, constituye la "nueva genética" puede situarse entre los años 1975 y 1985. Ésta sería el resultado del desarrollo y aplicación al análisis gené tico de todas las nuevas técnicas moleculares - restricción o fragmentación de enzimas, hibridación, secuenciación de ácidos nucleicos - Ello ha determinado la posibilidad, no sólo de estudiar los genes, sino de localizarlos, identificar sus funciones, aislarlos y transferirlos del genoma de unas células a otras, de unos organismos a otros. Se comenzaba así a poder manipular directamente fragmentos de ADN.
} 
Entre los avances científicos que, en la actualidad, demandan una mayor reflexión ética y jurídica se encuentran las técnicas de clonación y su posible aplicación al ser humano. Ciertamente, a raiz de la obtención, en 1997, de la oveja Dolly, por el Instituto Roslin de Escocia ${ }^{4}$, se reactivó un debate que, en el ámbito científico, se había iniciado hace algunos años. En concreto, la polémica surgió cuando la Universidad George Washington admitió, hace unos años, que había conseguido, mediante la técnica de la clonación, producir en un laboratorio, a partir de un embrión humano, más embriones con el mismo genoma . Sin embargo, a diferencia de lo que ocurrió en febrero de 1997, tal experimento no llegó a término.

En la actualidad nos hallamos inmersos en un debate social que, a pesar de tener su punto de partida en la clonación de mamíferos, se ha centrado, casi exclusivamente, en el problema de la licitud moral y juridica de la clonación de seres humanos ${ }^{7}$. Tras la

3

3 Los primeros ensayos de clonación con éxito se remontan a los años cincuenta. No obstante, el principio de la enucleación de un ovocito para servir de incubadora a una célula fue propuesto, en 1938, por el embriólogo alemán HANS SPEEMAN (Postel-Vinay O, Millet A., "¿Qué tal, Dolly?". Mundo científico, 1997, 180, pág. 536).

${ }^{4}$ El resultado del famoso proyecto, llevado a cabo por Wilmut, I., SCHNIEKE, A.E., McWhir, J y CAMPBELL. K.H.S., se publicó el 27 de febrero de 1997 en la Revista Nature, con el titulo de "Viable offspring derived from fetal and adult mammalian cells" (1997, 385, pág. 810-3). Hasta esa fecha, debido a anomalías cromosómicas que inducían la suspensión del desarrollo, los fracasos con mamiferos habian sido muy altos. Wilmut y su equipo introdujeron la novedad de la suspensión del ciclo de las células donantes. Este aspecto puede llegar a considerarse decisivo, aunque todavia es prematuro realizar una valoración.

${ }^{5}$ De cualquier forma, conviene tener en cuenta que existen publicaciones referentes a clonación por transferencia de núcleos desde los años 70. Por ello, resulta llamativa la inquietud generada en medios científicos tras la obtención de la oveja Dolly (Vid. Winston R., "The promise of cloning for human medicine", Bulletin of Medical Journal, 1997, 314. pág. 913)

${ }^{6}$ Schettles consiguió clonaciones en seres humanos, con obtención de cigotos que se multiplicaron hasta producir embriones. El procedimiento consistió en tomar el núcleo de la célula de un varón, eliminar el núcleo de un óvulo, e insertar el núcleo de la célula somática en la germinal. Se comprobó que el óvulo manipulado se comportaba igual que uno fecundado por un espermatozoide (Vid. Schettles, L.B., "Diploid nuclear replacement in mature ova with clevage", en American Journal of Obstretrics and Gynaecology, 133, 1976, pág. 22).

VID. PENNISI, E., "The lamb that roared", Science, 1997, 278, pà gs. 2038-9. De cualquier forma, es importante dejar constancia de que la clonación de animales no carece de relevancia ética y jurídica. En principio, conviene destacar que la aplicación de las técnicas de clonación a animales puede tener unas consecuencias positivas para los seres humanos. La Organización Mundial de la Salud (OMS) ha señalado que tal téenica abre la posibilidad de hacer progresar la investigación biomé dica sobre el diagnóstico y el tratamiento de enfermedades que afectan al hombre. Disponer de organismos genéticamente idénticos puede ayudar a dilucidar la etiología de las enfermedades (Organizzazione Mondiale della Sanitá, "Declaration sur le clonage", publicado en Medicina e Morale, 2, 1997, pág. 323-7). Por otro lado, hay que destacar que todas las Compañias farmacéuticas con actividad basada en la investigación utilizan en la actualidad la ingeniería gené tica como técnica habitual. En este sentido, la clonación de animales transgé nicos, productores de nuevas proteirias terapéuticas, ha suscitando un gran interés en esas Compañias. Frente a ello se plantean algunos problemas éticos: en primer lugar, si la experimentación genética en mamíferos es ajena a todo limite. En este sentido, nos podemos preguntar: ¿cualquier beneficio humano justifica la clonación animal? ¿o habrá que determinar los tipos de bienes en juego? Por otra parte, un posible éxito terapé utico o alimentario ¿ justifica someter a los animales a técnicas y ensayos que los van a modificar radicalmente o les van a ocasionar graves perjuicios? La Comisión Nacional de Bioética de Italia ha manifestado que la clonación de animales y vegetales (exceptuando el hombre) puede ser aceptada si tiene una finalidad que se corresponda con la promoción del bien humano o ambiental, en particular terapé utico, y no se reduce sólo a términos de lucro comercial; si no ocasiona en los animales sufrimientos no justificados y no 
polémica subyace, en gran medida, la convicción, expresada por muchos, de que, dado el estado actual de la ciencia, la clonación de seres humanos es sólo una cuestión de tiempo. En este sentido, por ejemplo, se ha manifestado el Protocolo sobre Clonación. Documento adicional a la Convención de Bioética elaborada por el Consejo de Europa, al considerar "que la clonación de seres humanos puede llegar a ser una posibilidad técnica".

Tras la publicación del experimento llevado a cabo en Escocia por el equipo de Wilmut, se puso reiteradamente de relieve, desde diversas instancias e instituciones, la gravedad ética y jurídica que reviste el hecho de llegar a instrumentalizar a los seres humanos mediante la clonación. El debate se centró, básicamente, en el empleo de dicha técnica con fines de reproducción humana. La presión social fue tan fuerte que, incluso, se aprobaron, con inusitada rapidez, mecanismos jurídicos para impedir tal tipo de conductas. $^{8}$. Las reacciones se produjeron tanto a nivel de Organismos internacionales como en el Derecho interno de diversos países ${ }^{9}$. Pero conviene destacar que algunos de estos instrumentos jurídicos tipifican, fundamentalmente, el empleo de la técnica de la clonación con fines reproductivos. Así, por ejemplo, en la Declaración sobre clonación, aprobada el 18 de marzo de 1997 por la Organización Mundial de la Salud $(\mathrm{OMS})^{10}$, se señala que la utilización de la clonación para reproducir seres humanos no es aceptable éticamente por violar el respeto debido a la dignidad de la persona y la protección de la seguridad del material genético humano. La OMS adoptó, como base de su Declaración, las Conclusiones obtenidas, en 1992, por el Grupo científico creado para estudiar los aspectos técnicos de la procreación médicamente asistida, en el marco del Programa de Investigación y Desarrollo en reproducción humana.

proporcionados con el bien que se va a conseguir y no supone un implicito atentado o riesgo para la biodiversidad (Comitato Nazionale per la Bioetica, "La clonazione come problema bioetico". Medicina e Morale, 1997, 2, pág. 360-2). Interesa destacar este último requisito porque, con frecuencia, se ha críticado la obtención de ganado clónico, presentándolo como un peligro, al suponer un atentado contra la biodiversidad. Esta afirmación es difícil de mantener en la actualidad, debido a la escasa eficacia que muestran estas técnicas. Algunos autores sostienen que, posiblemente, no llegue a plantearse nunca como un problema real. Desde su punto de vista, no es lógico que pueda llegarse a una situación en la que todos los rebaños sean clónicos. Existirían pequeños rebaños con diferencias genéticas entre unos y otros, resultado de perseguirse distintos objetivos mediante tales técnicas. A pesar de ello, cabría hacerse la pregunta de cara a un futuro no tan lejano, cuando la técnica esté más desarrollada. En mi opinión, la clonación y potenciación de los caracteres genéticos más rentables cualitativa y cuantitativamente puede implicar, a largo plazo, un serio atentado a la biodiversidad.

El Bulletin of Medical Ethics ha realizado una recopilación, en sucesivos números, de la situación legal de la clonación humana en diferentes paises (Vid. Bulletin of Medical Ethics, 1997, núm.125, págs. 3-5; núm. 126. págs. 4-8 y núm. 127, pág. 7).

"Vid. WILLIANS, N., "Cloning sparks calls for new laws", Science, 1997, 275, pág. 1415.

${ }^{10}$ Organizzazione Mondiale della Sanità, "Declaration sur le clonage", publicado en Medicina e Morale, 2, 1997, pág. 323-7. 
Desde hace algún tiempo, el debate ético y jurídico sobre la clonación humana ha sufrido un importante giro. El tema de fondo ya no es tanto la posible justificación del uso de la técnica de la clonación con fines reproductivos, sino su utilización para otros objetivos; así, por ejemplo, para la obtención de tejidos susceptibles de trasplante ${ }^{11}$. Es lo que actualmente se suele denominar "clonación terapé utica" ${ }^{12}$. En la raíz de este cambio se encuentra, en gran medida, el descubrimiento del potencial terapéutico de las denominadas células madre -o totipotentes-, extraídas de embriones humanos (Human Embryonic Stem Cells). Se trata de células no diferenciadas, a través de las cuales se cree que va a ser posible dar lugar a casi todos los tejidos humanos. Precisamente, en el mes de noviembre de 1998, se anunció, públicamente, que dos Centros de Investigación Americanos, la Universidad de Wisconsin -con el profesor James Thomson al frente- y la Universidad Johns Hopkins, -con un proyecto dirigido por el profesor John Geaghart- habían obtenido, a partir de embriones iniciales, tales células. El objetivo que se proponían era cultivarlas y conseguir que fueran capaces de originar tejidos susceptibles de ser utilizados, posteriormente, para trasplantes y tratamiento de enfermedades. Para conseguir tales células totipotentes es necesario destruir los embriones de los que se han extraído.

Algunos científicos afirman que, al combinar este descubrimiento con las técnicas de clonación humana por transferencia de núcleos, se crean unas excelentes perspectivas para la investigación científica, ya que es posible obtener las referidas células madre con una dotación genética predeterminada. De este modo, los tejidos obtenidos no serían susceptibles de rechazo en los trasplantes. Como ya he señalado anteriormente, estos descubrimientos han tenido como efecto fundamental un giro en el debate sobre la clonación humana. Una consecuencia práctica de este cambio es la actual distinción entre "clonación terapéutica" y "clonación reproductiva". Mientras que la clonación con fines reproductivos es actualmente rechazada de forma mayoritaria por científicos y juristas, la opinión no es la misma cuando se trata de clonación de embriones con fines de obtención de tejidos u órganos. En este sentido, merece destacarse, por ejemplo, el alegato, firmado por 67 premios Nobel, y publicado el mes de marzo de 1999 en la revista Science, a favor de la financiación, con fondos públicos, de la investigación en embriones humanos en EEUU.

También en España, Jose Antonio Abrisqueta, Jefe de la Unidad Médica de Genética Humana del Consejo Superior de Investigaciones Científicas (CSIC), se ha mostrado partidario de clonar embriones humanos con fines "terapéuticos", pero

\footnotetext{
"ALLMERS, H., "Ethics of cloning", Lancet, 349, 1997, pág. 1401.

${ }^{12}$ En mi opinión este término no es, en absoluto, adecuado, ya que da origen a confusión y malentendidos Difícilmente se puede hablar de una técnica "terapéutica" cuando no se realiza en beneficio del sujeto de la misma sino, más bien al contrario, su vida se sacrifica al servicio de fines ajenos a su propia salud o bienestar.
} 
nunca con "fines reproductivos". En este sentido, se manifiesta favorable a utilizar la técnica de la clonación para lograr las referidas células madre, que puedan dar lugar a tejidos susceptibles de trasplante o tratamientos de alteraciones del sistema nervioso.

En definitiva, en el debate ético y jurídico sobre la denominada "clonación terapéutica" encontramos, en la actualidad, dos grandes líneas argumentales, cuyas consecuencias prácticas son divergentes.

1. En primer lugar, la denominada perspectiva "tecnológica" ${ }^{13}$. Se parte del presupuesto de que la clonación, entendida como una mera técnica, es algo neutro desde un punto de vista ético. Por ello, carece de bondad o maldad intrínseca. La calificación moral, y su consiguiente aceptación jurídica, dependerá, exclusivamente, de los fines u objetivos que la motiven. Se trata de un punto de vista consecuencialista que condiciona la licitud de la experimentación en embriones humanos a los motivos que determinan el ensayo o a sus consecuencias posteriores. Desde este enfoque, por ejemplo, no se cuestiona si clonar seres humanos es o no respetuoso con la dignidad humana. Básicamente, se plantea su utilidad para el resto de la población. De este modo, para determinar su licitud jurídica, habría que calibrar su conveniencia mediante un proceso de ponderación del tipo beneficio/costo.

2. En segundo lugar, se discute la licitud ética y jurídica de la clonación humana "terapéutica" desde el presupuesto del necesario reconocimiento de la dignidad humana. Desde este punto de vista, la clonación supondría, básicamente, la instrumentalización de una vida humana, la del embrión, al servicio de fines, quizás muy loables, pero totalmente ajenos a su propia salud o bienestar. Sobre ello volveremos más adelante.

El objetivo del presente trabajo es analizar la problemática ética y jurídica que subyace a la clonación de embriones humanos con fines distintos a la reproducción humana. Ya he señalado que el tratamiento de este tema debe comenzar con una breve exposición de las bases biológicas del mismo. A ello dedicaremos las pá ginas siguientes.

\section{Bases biológicas de las técnicas de clonación}

Clonación significa producción asexuada de organismos o de líneas celulares genéticamente idénticas. En el presente estudio, voy a referirme, exclusivamente a la clonación de organismos. Este proceso se puede llevar a cabo de dos formas: por división celular y por transferencia de núcleos.

\footnotetext{
${ }^{13}$ Vid. KASS, L.R., "Clonación: La naturaleza no es prescindible", Cuadernos de Bioética, 1997, núm. 3, pág. 1194-5.
} 


\section{II.1. Clonación por división celular}

La técnica de la clonación por división celular, consiste, básicamente, en la partición de embriones (bisección) o separación de blastómeros en los primeros estadios de desarrollo embrionario. Se ha utilizado de forma experimental en animales de laboratorio. El método consiste en separar las células embrionarias y conseguir que se desarrollen independientemente las unas de las otras para producir embriones idénticos ${ }^{14}$. Esta técnica es similar al mecanismo que en la naturaleza conduce a la formación de gemelos monocigóticos ${ }^{15}$.

Conviene reseñar que, ya en el año 1991, Jerry Hall y Sandra Yee comprobaron que era posible separar células del embrión elaborando una zona pelúcida sintética con gel de polialginato. Este trabajó sirvió para que, en 1993. Hall y Stillman obtuvieran embriones humanos clónicos ${ }^{16}$.

${ }^{14}$ Sobre esta técnica VID. GINDOFF, P.R., "Clonación por separación embrionaria", En las Fronteras de la Vida: Ciencia y Ética de la Clonación. Fundación de Ciencias de la Salud, Madrid, 1998, pág. 52-61.

${ }^{15}$ VID. LACADENA, J.R., "La clonación: aspectos científicos y éticos", Anales de la Real Academia de Farmacia, núm. 63, 1997, pág. 289. Conviene poner de manifiesto que la identidad de los clónicos es relativa. Un ejemplo de ello lo ofrece la naturaleza con los gemelos monocigóticos, individuos que son genéticamente idénticos, con el mismo patrimonio genético. Sin embargo, posteriormente no resultan iguales: hay una serie de diferencias motivadas por el factor ambiental. Éste no es sólo el hecho educacional, sino también la alimentación intrauterina. Pueden tener rasgos y caracteristicas fisicas comunes, pero no existe igualdad completa. Incluso en los gemelos, las huellas dactilares son distintas.

${ }^{16}$ Utilizaron 17 embriones de entre 2 y 8 células fertilizados in vitro y no aptos para la implantación por tener una mayor dotación cromosómica de la normal, al haber sido fecundados por varios espermatozoides. Separaron los blastómeros y después los recubrieron con una zona pelúcida sinté tica. Estos blastómeros comenzaron a dividirse al ser depositados en una solución nutriente. Se obtuvieron 48 embriones. El desarrollo de los blastómeros fue distinto según su procedencia: los procedentes de embriones de 8 células se desarrollaron sólo hasta la etapa de 8 células; los obtenidos de embriones de 4 células llegaron hasta las 16 células; y únicamente los blastomeros procedentes de embriones de 2 células alcanzaron la etapa de 32 células necesaria para la implantación. Este ensayo se presentó en el Congreso de la Sociedad Americana de Fertilidad celebrado, en 1993, en Montreal con el título de Experimental Cloning of Polyploid Embryos Using an Artificial Zona Pellucida (VID. MARWICK, C. "Feds may fud study of existing embryos only" , 1995, JAMA, 273 (2), pág. 98). La comunidad científica guardó silencio sobre esta noticia hasta que The New York Times la desveló. Algunos investigadores sostienen que estos estudios deberían mantenerse en secreto. Según el Doctor David Meldrum, director del Centro de Reproducción Avanzada en Redondo Beach (California), "no es bueno que se hable de la clonación de embriones humanos", ya que "el público se siente incómodo cuando nos inmiscuímos en el proceso reproductivo y verá ésto como otro paso en la resbaladiza pendiente de la interferencia con la propia creación de la vida" (Bayo, C.E, "La primera clonación de embriones humanos, realizada con éxito en EEUU", manifestaciones publicadas en Diario 16, 25-X93). Conviene hacer constar que la obtención de estos embriones clonados fue discutida, aunque, basicamente, por razones de carácter formal: falta de permisos, de información, carencia del consentimiento informado de los donantes, etc... (Vid. Holden, C., "Embryo cloners jumped the gun", 1994, Science, 266, pág. 1949; Macklin. R., "Cloning without prior approval: a response to recent disclosures of noncompliance", Kennedy Institute of Ethics Journal, 1995, 5 (1), págs. 57-60). 


\section{II.2. Clonación por transferencia de núcleos.}

Esta segunda técnica se basa en la transferencia o transplante de núcleos a óvulos o cigotos a los que, a su vez, se les ha extraído el núcleo-enucleados- ${ }^{17}$. Los núcleos transferidos pueden tener varias procedencias:

a) De células embrionarias no diferenciadas.

b) De células somáticas diferenciadas.

Los experimentos de clonación por transferencia de núcleos de células embrionarias se iniciaron en la década de los 50 en anfibios. Así, Briggs y King observaron que, al transplantar núcleos de blástula, el desarrollo se completaba con normalidad, mientras que, al utilizar núcleos procedentes de estadios más avanzados, disminuía progresivamente su capacidad para dar lugar a un nuevo desarrollo normal. En 1952 consiguieron ejemplares de ranas idénticas por introducción, en óvulos, de núcleos celulares procedentes del intestino de renacuajos embrionarios ${ }^{18}$. De ello se podía deducir que las células diferenciadas no eran totipotentes. Sin embargo, más tarde, Gurdon y Kobel demostraron la falsedad de la anterior conclusión, al obtener clones a partir de células diferenciadas de renacuajo.

La clonación de anfibios estimuló el siguiente paso: los transplantes nucleares en ratón, vaca y oveja. Se obtuvieron individuos normales en mamíferos a partir de núcleos procedentes de células embrionarias, o bien de sus correspondientes cultivos celulares primarios. En 1986, Willadsen consiguió el desarrollo normal de carneros a partir de embriones de 8 ó 16 células fusionados con la mitad anucleada de un ovocito en metafase II, demostrando que los núcleos de los blastómeros eran totipotentes ${ }^{19}$.

En cuanto a la clonación por transferencia de células somáticas, ya he señalado que la Universidad George Washington de EEUU admitió, hace unos años, que había conseguido, mediante esta técnica, producir en un laboratorio, a partir de un embrión humano, más embriones con el mismo genoma. Sabemos que un nuevo hito, en la imparable marcha de la clonación, se produjo en el año 1997. El equipo del Instituto

${ }^{17}$ GRIFFIN, H.D., "Clonación por transferencia de núcleos", En las Fronteras de la Vida: Ciencia y Ética de la Clonación, Fundación de Ciencias de la Salud, Madrid, 1998, pág. 62-76

${ }^{18}$ BRIGGS, R.; KING, T., "Transplantation of living nuclei from bastula cells into enucleated frog 's eggs", Proc. NaH. Acad. Science, USA, 1952, 38, pág. 455-463. En 1975. Bromhall logró la multiplicación de clones de conejos. Experimentos semejantes son debidos a Hoppe, del Jackson Laboratoryen Bar Harbor y, a principios de la década de los ochenta, a Mc Grath y Solter (Vid. Santos Ruiz, A., "Manipulación genética e intervención en embriones", en Polaino-Lorente (edit.). A., Manual de Bioética General, Rialp, Madrid, 1994, pág. 184-185).

19

"WILLADSEN, SM,. "Nuclear transplantation in sheep embryos", Nature, 1986, 320, pág. 63-5. En relación a la clonación de ovejas y vacas vid. Willadsen, S.M., "Cloning of sheep and cow embryos", Genome, 1989, 31, pág. 956-62. 
Roslin obtuvo ovejas viables por reconstrucción de embriones a partir de cultivos celulares procedentes de discos embrionarios de blastocistos ${ }^{20}$ de 9 días, de fibroblastos de fetos de 26 días y de epitelio de glándula mamaria de una oveja adulta de 6 años en el último trimestre de gestación. De esta forma se obtenía el primer mamífero clonado a partir de una célula diferenciada ${ }^{21}$.

Es interesante hacer notar que la obtención de clones por transferencia de núcleos de células somáticas diferenciadas resulta de mayor interés científico que la consecución de clones por transferencia de núcleos de células embrionarias. Gran parte de la importancia de utilizar como donadores de ADN a individuos adultos radica, desde el punto de vista de sus posibles aplicaciones en mamíferos, en su "valor genético probado" ${ }^{22}$. Sin embargo, conviene reseñar que, en el caso de la obtención de clones mediante la técnica de transferencia o transplante de núcleos diploides a ovocitos, óvulos o cigotos enucleados, hay que tener en cuenta que, aunque la mayor parte del ADN celular se encuentra en el interior del núcleo de la célula, conformando los cromosomas, también hay otra porción de éste en las mitocondrias, estructuras

20

${ }^{20}$ Esta técnica ya fue desarrollada por Wilmut en 1996.VID. CAMPBELL, K.H.S., McWhir J., Ritchie, W.A, Wilmut I., "Sheep cloned by nuclear transfer from a cultured cell line", Nature, 1996, 380, pá g. 64-6.

21

Posteriormente, varios laboratorios han empleado una técnica similar para obtener clones de ratones y ganado (Vid. TSUNODA, Y y otros, "Eight calves cloned from somatic cells of a single adult". Science, diciembre, 1998. núm. 282, págs. 2095-2098). Ello confirma la repetibilidad de la técnica mediante la que se obtuvo la oveja Dolly (Vid. Wilmut, I., "Clonación con fines mé dicos", Investigación y Ciencia, febrero, 1999, núm. 269, págs. 24-29).

El profesor Santamaría, titular de Histologia de la Universidad Autónoma de Madrid, sostiene que este experimento se llevó a cabo en ovejas, y no en ratones u otros animales, debido a que en la oveja, cuando se produce la fecundación, el tiempo que tarda el núcleo en reaccionar para formar un embrión más maduro es bastante largo. En el hombre o en el ratón es mucho más corto, y se precisa en la clonación un tiempo más extenso para que el núcleo reorganice el ADN.

En el desarrollo de las técnicas de clonación animal se ha abierto un nuevo capitulo con la consecución de embriones fruto de la fusión de óvulos de vaca con células de primates, ratas, cerdos y ovejas adultas. Siguiendo la técnica desarrollada por el Instituto Roslin, Neal First, primer investigador que clonó mamíferos utilizando células no diferenciadas de embriones bovinos, comprobó que la transferencia de material gené tico de diferentes mamíferos a los óvulos de vaca se produjo con éxito en todos los casos, pese a proceder de especies muy diferentes. Sin embargo, cuando fueron implantados en hembras de las especies apropiadas para su futuro crecimiento, las gestaciones no culminaron con éxito. Posiblemente a causa de no haber eliminado todo el material genético de los óvulos de vaca.

También en esta línea, la Compañía Americana "Advanced Cell Technology" ha anunciado haber conseguido desarrollar células híbridas con material genético humano y de vaca. La técnica consistió en introducir el ADN de núcleos de células humanas somáticas en óvulos de vaca previamente enucleados La fusión de ambos elementos se realizó con una descarga eléctrica. La Compañía alega, en defensa de estas técnicas, que su objetivo es la producción de órganos para transplantes evitando los problemas de rechazo. Para la creación de la célula híbrida los científicos utilizaron células donadas por uno de los investigadores. Múltiples especialistas, así como la Asociación de la Industria Biotecnológica Americana, han realizado un llamamiento al Gobierno americano para que imponga directrices claras en estas líneas de investigación.

LACADENA, J.R., "La clonación: aspectos científicos y éticos", Anales de la Real Academia de Farmacia, núm. 63. 1997. pág 277. 
celulares situadas en el citoplasma ${ }^{23}$. De este modo, se puede afirmar que los individuos clónicos obtenidos por transferencia de núcleos tienen menor grado de identidad que dos gemelos monocigóticos, porque los citoplasmas de sus células son diferentes. Ello determina que mediante esta técnica nunca se pueda llegar a conseguir clones con idéntica carga genética ${ }^{24}$.

Ya hemos señalado anteriormente que mediante la técnica de clonación por trasferencia de núcleos, en la medida en que la carga genética de un embrión proviene de la célula somática de un adulto, es posible obtener células y tejidos susceptibles de trasplante sin problemas de rechazo. Hemos destacado que en ello tiene mucho que ver el hallazgo de las llamadas embryonic stem o células madre embrionarias. Su origen puede situarse en 1981, cuando un grupo de científicos estadounidenses hizo público el logro de cultivos de estas células obtenidas a partir de embriones de ratones en sus primeros estadios de desarrollo ${ }^{25}$. Posteriormente, Thomson demostró que las células embrionarias humanas eran capaces de formar una amplia variedad de tejidos cuando se las transplantaba bajo la piel de ratones. Desde esta perspectiva, se ha señalado que la obtención de embriones humanos mediante clonación por transferencia de núcleos de células somáticas abriría amplias posibilidades en el campo de la biomedicina ${ }^{26}$.

Sin embargo, conviene tener en cuenta que la utilización de embriones no es la única vía para obtener células madre. En 1999, el investigador italiano Angelo Vescovi

${ }^{23}$ La mitocondria es un orgánulo celular que está presente en el citoplasma de todas las células de los eucariotas. En los seres humanos cada mitocondria contiene alrededor de 10 cromosomas. El cromosoma mitocondrial es circular y consta de 16.569 pares de bases. Los cromosomas en una mitocondria dada son idénticos, salvo las posibles mutaciones. El número de mitocondrias por célula se mantiene bastante constante, si bien la cantidad varía con el tipo celular y el estado funcional. Actualmente, se conocen 59 trastornos genéticos de origen mitocondrial (VID. ABRISQUETA, J.A., "Mapa fisico-patológico de los cromosomas humanos", Anales de la Real Academia de Farmacia, 61, 1995, pág. 309-38). Sobre el ADN mitocondrial se puede consultar Wallace, D.C., "Función normal y patológica del ADN mitocondrial", Investigación y Ciencia, 253, 1997, pág. 12-20

24

De este modo, el ADN de Dolly tuvo dos procedencias: el del núcleo, que es aportado por la célula diferenciada de un adulto, y el de la mitocondria que procede de un óvulo recién formado (VID. SPIER, R., "Clones on stage". Science and Engineering Ethics, 3. 1997, pág. 106-8). Este fragmento de ADN ha suscitado un elevado número de interrogantes que deben ser contestados en futuras investigaciones Entre otras interrogantes, podrian reseñarse las siguientes: ¿ están en los genes mitocondriales las órdenes del desarrollo embrionario?, ¿que tipo de acciones lo regulan desde el citoplasma?

VID. EVANS, M.J., Nature, 1981, núm. 292, pág. 154; MARTIN, G.R., Proceedings of the National Academy of Sciences, 1981, pág. 7634.

ALLMERS, H., "Ethics of cloning", Lancet, 349, 1997, pág. 1401. Algunos científicos han señalado que la clonación también facilitaría el estudio de la diferenciación celular, de gran importancia para los trasplantes (VID. KOLBERG, R., "Human embryo cloning reported", Science, 1993, 262, pág. 652-3). En este sentido, VEECK Lucinda, Directora de Embriología del Jones Institute for Reproductive Medicine de Norfolk. Virginia, entiende que las nuevas técnicas son muy valiosas para estudiar el desarrollo temprano de los embriones. En su opinión. también pueden ayudar a determinar la influencia de los distintos componentes del citoplasma en la embriogénesis. Otra finalidad sería la de obtener sujetos genéticamente idénticos para realizar estudios científicos. Es claro que, para la realización de un ensayo clínico, seria de gran ayuda tener una población lo más homogénea posible, de forma equiparable a como se lleva a cabo la experimentación animal. Todos estos fines, sin embargo, comportan graves riesgos para los embriones, e incluso su destrucción. 
publicó en la revista Science ${ }^{27}$ un experimento que dió un vuelco al debate sobre la clonación de embriones humanos. Vescovi y su equipo -compuesto por científicos del Instituto Nacional Neurológico de Milán y de la Compañía NeuroSpheres Limited, de Calgary (Canadá)- comprobaron que las células madre del cerebro de un ratón adulto pueden cambiar de identidad y dar lugar a otros tejidos y órganos. El experimento, por ello, trató de demostrar que no hace falta partir de un embrión para obtener células pluripotenciales que sean capaces de generar diversos tejidos u órganos. En febrero de 2002, científicos de la Universidad de Navarra confirmaron estas conclusiones. Lograron obtener células madre del propio organismo adulto, en concreto, del músculo del enfermo. Tales células, convenientemente cultivadas, fueron capaces de regenerar un corazón infartado.

He señalado anteriormente que, desde la denominada perspectiva "tecnológica", se entiende que el motivo que determina el ensayo de clonación es el factor decisivo para valorar su licitud ética y jurídica. Sin embargo, conviene no perder de vista que, tanto en el supuesto de la clonación con fines reproductivos, como en el caso de aquella que persigue la obtención de tejidos u órganos susceptibles de trasplante, el objeto de experimentación es un ser vivo, cuyo genoma lo identifica, ineludiblemente, como miembro de la especie humana. Por ello, el problema de la clonación de embriones humanos remite directamente a la cuestión del estatuto ético y jurídico del embrión humano. De este modo, el tratamiento jurídico de este tema no puede eludir la premisa del necesario reconocimiento de la dignidad inherente a todo ser humano. A ello dedicaremos el siguiente epígrafe.

\section{Aproximación a la noción de dignidad humana}

En la actualidad, es frecuente apelar al principio de la dignidad humana ${ }^{28}$, entendiéndolo como el fundamento último del orden moral y jurídico ${ }^{29}$. Esta referencia

\footnotetext{
${ }^{27}$ VESCOVI, A.L., "Turning brain into blood: a hematopoietic fate adopted by adult neural stem cells in vivo", Science, 22 de enero de 1999, núm. 283, pág. 534-537.

28

Ciertamente, soy consciente de que referirse a la noción de dignidad humana implica enfrentarse a un tema muy complejo que, en todo caso, necesitaría un desarrollo más amplio del que es posible otorgarle en esta sede. Ello queda ampliamente demostrado con sólo consultar la abundantísima bibliografía publicada sobre el tema. Vid., entre otros trabajos, SPAEMANN, R., "Sobre el concepto de dignidad humana", Persona y Derecho, XIX, 1988: Spaemann, R., Lo natural y lo racional: ensayos de antropología, trad. D. Innerarity y J. Olmo, Rialp, Madrid, 1989; Bristow, P. The moral dignity of man, Dublín, Four Courts Press, 1993; Arendt, H., La condición humana, Barcelona, Paidós, 1992; Bon, H., La muerte y sus problemas, Fax, Madrid, 1950; Sociedad Internacional provalores humanos E. Fromm y S. Zubirán (ed.), El ser humano y su dignidad ante la muerte, Instituto Nacional de la Nutrición Salvador Zubirán, México, 1989; Gentles, I. (ed.). A Time to Choose Life Women, Abortion and Human Rights, Stoddart, Toronto, 1990; Annas, G.J., "Death Without Dignity for Commercial Surrogacy. The Case of Baby-M", Hasting Center Report, 1988, Apr-May, 18; Freer, J.P. "Chronic vegetative States. Intrinsic Value of Biological Process", Journal of Medicine and Philosophy, 1984, 9; Gaylin, W., "In Defense of the Dignity of Being Human", Hasting Center Report, 1984, Aug., 14; Choza, J., "El descubrimiento de la dignidad humana", en Arechederra, J.J., Ayuso, P.P., Choza, J., Vicente, J. (eds.), Bioética, psiquiatría y Derechos
} 
a la noción de dignidad es especialmente clara en los numerosos Documentos internacionales que, desde hace algunos años, están surgiendo con el objetivo de establecer un marco ético y jurídico en relación a los avances de la biotecnología. Así, por ejemplo, merece destacarse que la Declaración Universal sobre el Genoma Humano y los Derechos Humanos, aprobada por la XXIX Conferencia de la UNESCO, el 11 de noviembre de 1997, comienza con un capítulo titulado "La dignidad humana y el genoma humano". Asimismo, los artículos 1 y 2 de dicho texto se refieren explícitamente a la dignidad intrínseca de todos los miembros de la familia humana.

En el mismo sentido, el Convenio sobre los Derechos Humanos y la Biomedicina del Consejo de Europa, sólo en su Preámbulo, se refiere a la dignidad humana tres veces, y su artículo 1 comienza destacando que "Las partes en este Convenio protegerán la dignidad e identidad de todo ser humano...". También la Declaración Ibero-Latinoamericana sobre ética y genética, aprobada en Argentina en 1998, sostiene que "la reflexión sobre las diversas implicaciones del desarrollo científico y tecnológico en el campo de la genética humana debe hacerse atendiendo al respeto a la dignidad; a la identidad y a la integridad humanas y a los derechos humanos recogidos en los instrumentos jurídicos internacionales". En definitiva, es claro que estos documentos tratan de enfatizar la idea de que, sólo partiendo del reconocimiento de la dignidad inherente a cada miembro de la especie humana, dignidad que se apoya en el genoma pero que no se reduce a él, será posible afrontar todos los problemas de carácter ético y jurídico que se plantean ${ }^{30}$.

Humanos, I.M. \& C., Madrid, 1995, Hendin, H., "Selling Death and Dignity", Hasting Center Report, 1995, 25 (3): Gonzalez, A.M., Naturaleza y dignidad, Eunsa, Pamplona, 1996; Gonzalez Pérez, J., La dignidad de la persona, Cívitas, Madrid, 1986; Millán Puelles, Persona humana y justicia social, Rialp, Madrid, 1978; Melendo, T., Millán, L., Dignidadi ¿ una palabra vacía?, Eunsa, Pamplona, 1996, etc..

29

En relación con los valores superiores de la Constitución española, Peces- Barba ha señalado que "la dignidad humana es el fundamento y la razón de la necesidad de esos valores superiores, es la raiz última de todo, y creo que su inclusión entre los valores superiores no es metodológicamente correcta, puesto que éstos son los caminos para hacer real y efectiva la dignidad humana" (Los valores superiores, Técnos, Madrid, 1984, pág. 85-86). También para León "el respeto a la dignidad del hombre, por el hecho de ser persona y libre, es el fundamento de toda ética" (León, F.J., "Dignidad Humana, Libertad y Bioética", en Persona y Bioética, núm, 1, 1997, pág. 143).

Sin embargo, en muchas ocasiones, el recurso a la noción de dignidad humana va acompañado de una patente imprecisión. La paradoja se presenta porque, por un lado, la apelación a la dignidad aparece como el último y más importante eslabón de un argumento. Señalar que algo es contrario a la dignidad humana se presenta como prueba irrefutable para su rechazo. Por otro, el significado que se atribuye a esta noción es tan ambiguo y variable que, en ocasiones, se convierte en una expresión vacia de contenido. En este sentido, hay que admitir, en palabras de J. González Pérez, que "en nombre de la dignidad se intentan justificar soluciones radicalmente contrarias sobre temas fundamentales tan de nuestros dias como la admisibilidad de ciertas formas de manipulación genética, el aborto, la disponibilidad de órganos humanos, los experimentos mé dicos con personas y la eutanasia" (La dignidad de la persona, ed. Cívitas, Madrid, 1986, pág. 19 y 20; vid. asimismo Melendo, T.; Millán-Puelles, L., Dignidad: ¿una palabra vacía?. Eunsa, Pamplona, 1996). Esto ha conducido a algunos autores, como por ejemplo Norbert Hoerster a mantener textualmente: "Cuan vacía es necesariamente la fórmula del principio de dignidad humana: no es nada más y nada menos que el vehículo de una decisión moral sobre la admisibilidad o inadmisibilidad de formas posibles de la limitación de la autodeterminación individual" (Hoerster, 
Ciertamente, el recurso a la idea de dignidad no es una novedad. Así, por ejemplo, la Constitución española, en su artículo 10.1, sostiene que "la dignidad de la persona, los derechos inviolables que le son inherentes...son fundamento del orden político y de la paz social". Por su parte, la Constitución Alemana, en su artículo 1 , mantiene que "la dignidad del hombre es inviolable". Sin embargo, es interesante hacer notar que, en un momento en el que la misma idea de dignidad humana es discutida, e incluso rechazada desde diversos sectores doctrinales, estos documentos insisten, de una manera rotunda, en su radical importancia.

¿Qué significa, pues, la noción de dignidad humana aplicada a las posibilidades de la nueva genética? Para aproximarnos a su significado, y poder comprender sus exigencias actuales, puede resultar interesante remontarnos hasta los orígenes de la misma noción. Esta hunde sus raíces más proíundas en el siglo $\mathrm{V}$ antes de Cristo. Es deudora de la noción de humanitas griega ${ }^{31}$. En el pensamiento griego, en concreto en el estoicismo medio, encontramos una visión universalista del ser humano, cuyo valor radica, en gran medida, en mostrar, claramente, la exigencia ética de respeto universal al otro, a cualquier otro, al que se considera otro yo. En este sentido, dirá Cicerón (10643 a. C.):

"Nada hay tan semejante a otra cosa como un hombre a otro. Cualquier definición del hombre vale para otro. Ello sólo resulta oscurecido en la medida en que el hombre se deja llevar por la corrupción de costumbres, y por la variabilidad del ánimo" ${ }^{32}$.

Esta idea es desarrollada y enriquecida por el cristianismo. La noción judía del hombre a imagen de Dios se universaliza. Se entiende así que todo miembro de la especie humana tiene un valor absoluto, porque posee una participación en la dignidad absoluta propia del Ser subsistente.

Para el pensamiento clásico, el principio tradicional de la dignidad de la persona significa que todo ser humano posee una excelencia o eminencia ontológica, una superioridad en el ser frente al resto de lo creado. Ello lo sitúa en otro orden del $\mathrm{ser}^{33}$.

\footnotetext{
N., "Acerca del significado del principio de la dignidad humana", en En defensa del positivismo jurídico, trad. J.M. Seña y revisión de E. GARZÓN VALDÉS y R. ZIMMERLING, Gedisa Editorial, Barcelona, 1992, pág. 91)

La humanitas, o conciencia de la igual dignidad de los hombres y la necesidad de un idéntico respeto a todos ellos, aparece, por primera vez, en la obra de Panecio de Rodas. Posteriormente será Cicerón el autor que más claramente refleje esta idea en su obra (Vid. sobre este tema Ballesteros, J., Sobre el sentido del Derecho, Técnos, Madrid, 1986, pág. 112).

${ }^{32}$ CICERÓN. De legibus, I, 10.

${ }^{33}$ HERVADA, J., Lecciones propedéuticas de filosofía del derecho, Eunsa, Pamplona, 1992, pág. 449.
} 
En esta línea, la dignidad implica algo absoluto ${ }^{34}$ y no meramente relativo, ya que la diferencia con los otros seres no es cuantitativa, sino cualitativa. Ciertamente, con el concepto de dignidad queremos significar, "grosso modo", la idea de respeto incondicionado que se debe al ser humano, al tratarse de algo "sagrado", al margen del ámbito del comercio. Desde esta perspectiva podría sostenerse, siguiendo a Hervada, que la dignidad es "la perfección o intensidad del ser que corresponde a la naturaleza humana y que se predica de la persona, en cuanto ésta es la realización existencial de la naturaleza humana" ${ }^{35}$.

También Kant entendió que las personas "no son meros fines subjetivos, cuya existencia, como efecto de nuestra acción, tiene un valor para nosotros, sino que son fines objetivos, esto es, cosas cuya existencia es en sí misma un fin, y un fin tal que en su lugar no puede ponerse ningún otro fin para el cual debieran ellas servir como medios ${ }^{\prime 16}$. Y, en otro fragmento de su Fundamentación de la Metafísica de las Costumbres, sostuvo: "aquello que tiene precio puede ser sustituido por algo equivalente, en cambio, lo que se halla por encima de todo precio y, por tanto, no admite equivalentes, eso tiene una dignidad" ${ }^{37}$.

Siguiendo a Spaemann, si el hombre, entre los demás seres, se hace merecedor de tal respeto absoluto, ello se debe a que él es real en sentido enfático, porque para él es real todo lo demás ${ }^{38}$. Para este autor, el hombre:

\footnotetext{
${ }^{34}$ Este era el sentido que ya Tomás de Aquino atribuia a esta noción. El sostenía que "el término dignidad es algo absoluto y pertenece a la esencia del sujeto" (Tomás de Aquino, Summa Theologica, I-I. Cuestión 42, artículo 4. edición de Biblioteca de Autores Cristianos, Madrid, 1993, pág. 411). En otro pasaje mantenía que "es evidente por sí misma cualquier proposición cuyo predicado pertenece a la esencia del sujeto" (Tomás de Aquino, Summa Theologica, I-II, Cuestión 94, artículo 2, op. cit., pág. 731). Utilizaba, por ello, el término dignidad como equivalente a principio axiomático. En realidad, si la dignidad, como dimensión intrínseca del ser humano, posee un carácter ontológico, mas que algo demostrable, es, como entendió Tomás de Aquino, la premisa de la demostración.

35

HERVADA, J., Lecciones propedéuticas de filosofía del derecho, op. cit., pág. 449. Por otro lado, conviene recordar que la posibilidad de aproximarnos al concepto de dignidad dependerá estrechamente de la teoría del conocimiento de la que partamos. Es evidente que el empirismo, al reducir todo el conocimiento a la experiencia sensible, no podrá llegar a admitir la idea de dignidad, al tratarse de un universal. Los universales son ideas, conceptos y enunciados que elabora nuestra mente, a partir de datos parciales, pero que no por ello carecen de cierta concordancia con la realidad. El universal es una construcción de la razón, pero, al mismo tiempo, es un reflejo de la realidad.

${ }^{36}$ KANT, E., Fundamentación de la metafísica de las costumbres, trad. M. GARCIA MORENTE, Real Sociedad Económica Matritense de amigos del Pais, 1992, pág. 64. Y en otro fragmento: "Los seres racionales llámanse personas porque su naturaleza los distingue ya como fines en sí mismos, esto es, como algo que no puede ser usado meramente como medio, y, por tanto limita en ese sentido todo capricho y es un objeto del respeto" (pág. 64).

${ }^{37}$ Fundamentación de la Metafísica de las Costumbres, trad. M. GARCIA MORENTE, Real Sociedad Económica Matritense de amigos del País, 1992, pág. 71.

SPAEMANN, R., Lo natural y lo racional, op. cit., pág. 147
} 
"es real en un sentido que no se puede reducir a ser objeto, es decir, a mero valor de una variable dependiente. El ente que tiene una relación consigo no es exclusivamente relativo a otro, ni a la experiencia de otro. En tanto que ser finito se halla también, ciertamente referido de modo esencial a otro, siendo real sólo en esta relación. Mas en la medida en que lo sabe, en la medida en que realiza su propia relatividad, y saliendo de su centralidad, se relativiza a sí mismo, suprime la relatividad en cuestión y deviene representación del absoluto. No es otra cosa lo que entendemos por dignidad humana" ${ }^{39}$.

Pero el ser humano no es sólo "un fin en sí mismo para sí o para los demás", sino "un fin en sí mismo por antonomasia". Como señala Spaemann, si el hombre es sólo un valor para sí mismo y no un "fin en sí mismo", no se puede hablar estrictamente de "pérdida de valor" cuando desaparece una vida humana: "Si todo valor es relativo al sujeto que valora, no se puede llamar crimen a la aniquilación completa de todos los sujetos que valoran... Sólo el valor del hombre "en sí" -no únicamente para los hombres- hace de su vida algo sagrado y confiere al concepto de dignidad esa dimensión ontológica sin la cual no puede pensarse siquiera lo que con ese concepto se quiere expresar ${ }^{40}$.

Por otro lado, frente a las actuales interpretaciones del pensamiento Kantiano ${ }^{41}$, efectuadas por autores como Engelhardt, quiero destacar que la dignidad no radica en la posesión de conciencia y autonomía moral, ni su contenido se traduce en un derecho general a la libertad. La dignidad, como ha señalado con mucho énfasis Ballesteros ${ }^{42}$, radica en el ser, no en el tener. La dignidad concurre antes de poseer los indicadores humanos (conciencia, capacidad de sufrimiento, autonomía, etc.), porque tales cualidades afectan al tener del hombre y no a su st: y por lo tanto no son notas universales. La dignidad, por ello, radica en aquello que todos los seres humanos tenemos en común, la naturaleza humana, y se encuentra en conexión con lo más

\footnotetext{
${ }^{39}$ SPAEMANN, R., Felicidad y Benevolencia, trad. J.L. del Barco, Rialp, Madrid, 1991, pág. 147.

${ }^{40}$ SPAEMANN, R., "Sobre el concepto de dignidad humana", en Persona y Derecho, XIX, 1988, pág 20-21.

${ }^{41}$ Como es bien conocido, entienden la dignidad de un modo inmanente, desvinculada de la idea de naturaleza humana, al considerar ésta como una instancia meramente empírica, carente de normatividad. En su Metafísica de las costumbres Kant se refiere a "la dignidad de un ser racional que no obedece a ninguna otra ley que aquella que él se da a sí mismo....como legislador en el reino de los fines, como libre respecto de todas las leyes naturales y obedeciendo sólo a aquellas que él mismo se dá.....la autonomía es, pues, el fundamento de la dignidad de la naturaleza humana y de toda naturaleza racional" (Kant, E., Fundamentación de la metafísica de las costumbres, trad. M. García Morente, Real Sociedad Económica Matritense de amigos del Pais, 1992, pág. 92-94). En definitiva, la dignidad se traduce, fundamentalmente, en la autonomía moral de la conciencia. Como ha señalado Hervada, el término final de esta forma de entender la dignidad es la anomia: el hombre es su propia ley (Hervada, J., op. cit., pág. 447)

${ }^{42}$

BALLESTEROS, J., "Sobre la fundamentación antropológica de la universalidad de los derechos humanos", Discurso leido en su recepción como Acadé mico de número de la Real Academia de Cultura Valenciana, Valencia, 1999, pág. 24.
} 
intrínseco a ella, sus fines. Así, se puede sostener que todo ser humano, titular de una dignidad ontológica, está llamado a comportarse de acuerdo con las exigencias derivadas de ésta dignidad, vinculadas a los fines de su propia naturaleza racional ${ }^{43}$. Tales fines están presentes en la constitución intrínseca del ser humano. La dignidad, por ello, implica que el ser humano merece un trato adecuado a su estatuto ontológico pero, además, él mismo debe comportarse de acuerdo con él. Hay comportamientos conformes (dignos) y disconformes (indignos) con ese estatuto. Ello justifica la existencia, no sólo de derechos, sino también de deberes naturales. La dignidad no implica, por ello, derechos y deberes autónomos, sino que el ser humano está vinculado por una normatividad inherente a su propio ser ${ }^{44^{\circ}}$.

En suma, la dignidad del hombre es la de un ser trascendentalmente libre, abierto a la realidad por la inteligencia y la voluntad. Se trata, como ya hemos señalado, de una dignidad ontológica, radical, ya que se apoya en la misma naturaleza del ser humano. Por ello, la dignidad es inseparable de la categoría "homo sapiens", con independencia de que se manifiesten externamente determinadas propiedades características de los miembros de tal especie. Por otro lado, no se trata de un derecho humano, sino de la fundamentación misma de los derechos humanos. Tales derechos no se derivarían de la atribución jurídica de la personalidad, concedida, a su vez, por la posesión de racionalidad o la capacidad de autodeterminación moral, sino de la dignidad. En este sentido, señala Spaemann que los derechos humanos "se deben reconocer para todo ser que descienda del hombre y a partir del primer momento de su existencia natural, sin que sea lícito añadir cualquier criterio adicional ${ }^{45}$. Para este

\footnotetext{
${ }^{43}$ Como es bien conocido, la crítica a este enfoque se ha apoyado, entre otros argumentos, en la ambigüedad del término "naturaleza". En mi opinión, el problema se resuelve cuando se adopta una perspectiva teleológica. En este sentido, ya señaló Tomás de Aquino que, en la medida en que lo más intrínseco a una cosa es su fin, de ésto se sigue que lo más intrínseco a la naturaleza humana no es cualquier acto voluntario, sino aquel acto voluntario que se oriente a ese fin (Summa Theologica, I-II, Cuestión 6, artículo 1, op. cit., pág. 103). En esta línea, señala A.M. GONZALEZ: "lo que constituye al vegetal en vegetal y lo distingue del animal es un fin que el vegetal no puede trascender... Aná logamente, lo que constituye al animal en animal y lo distingue del hombre es un fin que el animal no puede disponer... En la misma línea, lo que constituye al ser humano en ser humano-su naturaleza-y lo distingue de Dios es otro fin que el hombre no puede trascender.... Ello excluye la posibilidad de atribuir al hombre una absoluta autonomía. No sólo en su ser, sino también en su operar, el hombre tiene algo dado: los primeros principios; ellos son los que definen su naturaleza especifica" (GONZALEZ, A.M., Naturaleza y dignidad, Eunsa, Pamplona, 1996, pág. 97-99). Sobre el debate actual sobre la viabilidad de recurrir al concepto de naturaleza como guía moral vid., asimismo, CALLAHAN, D., "Can Nature Serve as a Moral Guide?", en Hasting Center Report, November-December 1996, 26 (6), pág. 21-22. En el mismo número pueden consultarse también Kass, L.R., "The Trouble Dream of Nature as a Moral Guide" y Norton, B. G., "Moral Naturalism and Adaptive Management".

${ }^{44}$ Frente a las posibles críticas de heteronomía que algunos puedan achacar a esta visión señalaría, siguiendo a Gabriel Marcel, que "La mayor parte de las insuficiencias del Kantismo se deben esencialmente al hecho de no haber visto que el sí mismo puede y debe ser trascendido, sin que por eso la autonomía ceda a la heteronomía" (MARCEL, G., Etre et Avoir, París, Aubier, 1935, pág. 254).

${ }^{45}$ SPAEMANN, R, Lo natural y 10 racional, op. cit., pág. 50. A.M. GONZALEZ sostiene que "precisamente esa dignidad se pone en juego cuando cualquiera se arroga el derecho de decidir que seres merecen el nombre de personas y cuáles no. Porque entonces facilmente se pasa a considerarlos como un puro medio, y se les somete a
} 
autor, "si la pretensión de pertenecer a la sociedad humana quedara al juicio de la mayoría, habríamos de definir en virtud de que propiedades se posee dignidad humana y se pueden exigir los derechos correspondientes. Pero esto sería suprimir absolutamente la idea misma de los derechos humanos. Estos presuponen que todo hombre, en tanto que miembro de la humanidad, puede hacer valer sus derechos frente a otros, lo cual significa a su vez que la pertenencia a la especie homo sapiens sólo puede basarse en aquella dignidad mínima que hemos llamado dignidad humana" ${ }^{46}$.

En nuestra opinión, de esta visión ontológica de la dignidad es posible extraer, entre otras, las siguientes consecuencias en relación al tema que nos ocupa:

$1^{\circ}$. Se trata, como se ha señalado, de una condición propia e inherente a todo ser humano, por lo que no admite grados o jerarquías. En consecuencia, debe ser reconocida, en la misma medida, a cualquier miembro de la categoría homo sapiens, con independencia de su estado de desarrollo o características físicas o mentales. En este sentido, el Preámbulo de la Convención sobre los Derechos Humanos y la Biomedicina del Consejo de Europa establece "la necesidad de respetar al ser humano, no sólo como individuo sino también en su pertenencia a la especie humana", reconociendo la importancia de garantizar su dignidad. Ya he señalado que en su artículo primero se refiere, también, a la protección de la dignidad de todo ser humano.

$2^{\circ}$. De esta dignidad se derivan ciertos derechos y deberes. El primer derecho fundamental es el derecho a la vida, ya que su lesión implica la negación radical de la misma dignidad inherente al ser. Todo ataque a una vida humana se traduce en la destrucción misma de la dignidad que en ella radica. En este sentido, el artículo 2, apartado a) de la Declaración Universal sobre el Genoma Humano y los Derechos Humanos, mantiene que "Cada individuo tiene derecho al respeto de su dignidad y derechos, cualesquiera que sean sus características genéticas", $Y$ en su punto b) afirma que "Esta dignidad impone que no se reduzca a los individuos a sus características genéticas y que se respete su carácter único y su diversidad".

$3^{\circ}$, La dignidad del ser humano conlleva la exigencia jurídica de no instrumentalización del mismo y de no comercialización de sus partes. Por ello, debe

cálculos utilitaristas. Los débiles, los improductivos, los lisiados, los niños, los enfermos, podrían irse excluyendo progresivamente de la definición de persona, y la exclusión podría facilmente justificarse atendiendo a razones de Estado y en última instancia de conveniencia. Frente a esto, no está de más recordar que la dignidad, a diferencia del valor, no es conmensurable" (Naturaleza y dignidad, op. cit., pág,. 54-55). En el mismo sentido se ha manifestado la Asociación Médica Mundial: "La afirmación de la dignidad de la persona humana constituye la medida de las intervenciones biológicas, genéticas y mé dicas sobre el hombre desde su concepción hasta el último suspiro y aún más allá" (cit. en SERRANO RUíz-CALDERÓN, J.M., "Genética y derechos humanos", en Bioética y Derechos Humanos, Servicio de publicaciones de la Universidad Complutense, 1993, pág. 46),

${ }^{46}$ SPAEMANN, R., "Sobre el concepto de dignidad humana", op. cit., pág. 25. 
entenderse como un principio fundamental la primacía del ser humano frente a cualquier tipo de interés social o económico. En relación al principio de no instrumentalización, el artículo 2 de la Convención sobre los Derechos Humanos y la Biomedicina afirma que "El interés y el bienestar del ser humano prevalecerán frente al exclusivo interés de la sociedad o de la ciencia". De ahí se derivaría la prohibición legal de la clonación humana con fines de obtención de tejidos para trasplantes.

4․ Otra de las exigencias derivadas de la noción de dignidad humana sería el necesario respeto a la unicidad e individualidad de cada ser humano ${ }^{47}$. En consecuencia, cada ser humano debe ver reconocido un derecho a poseer un propio y original patrimonio genético, y a expresarlo sin interferencias que puedan perjudicar su integridad o disminuir su originalidad ${ }^{48}$. La intervención en un patrimonio genético ajeno es una intromisión injustificada en la individualidad de un miembro de la especie humana. Desde esta perspectiva, es claro que toda clonación de un embrión supone también un atentado a tal unicidad biológica del sujeto humano. En este sentido, Galibert mantiene que la clonación humana debe ser totalmente prohibida, debido a que la esencia de la humanidad se encuentra en la singularidad de cada uno de sus miembros, resultado de la única recombinación de dos genomas únicos ${ }^{49}$.

\section{Dignidad y clonación de embriones humanos}

Al comienzo del trabajo hemos hecho referencia a la actual distinción entre clonación con fines reproductivos y clonación dirigida a la obtención de tejidos u órganos susceptibles de trasplante o clonación "terapé utica". También hemos señalado que es frecuente que, partiendo de presupuestos consecuencialistas, la valoración ética y jurídica de cada una de estas técnicas sea diferente. Asi, por ejemplo, en el Congreso organizado por la UNESCO, en mayo de 1997, bajo el título de "Biotecnología animal, clonación y tecnología transgénica", gran número de participantes enfatizaron la distinción entre la clonación reproductiva en seres humanos, destinada al nacimiento de un individuo, y las técnicas no reproductivas de clonación con fines de investigación o de obtención de tejidos.

\footnotetext{
${ }^{47}$ Lacadena afirma que hay que tener en cuenta que "la propiedad de unicidad (ser único e irrepetible) junto con la unidad (ser uno sólo) son fundamentales en el proceso de individualización del ser humano" (LACADENA, JR. "La clonación: aspectos científicos y éticos", Anales de la Real Academia de Farmacia, 1997; 63: 291). 48 GAFO J., 10 palabras clave en Bioética, Estella,Verbo divino, 1993, pág. 230.

${ }^{49}$ A esta afirmación BAKER contesta diciendo que, en ese caso, ¿qué hacemos con el $1 \%$ de la población que son gemelos monocigoticos si ellos no son esencialmente humanos? (BAKER M.R, "Cloning humans", Nature, 1997. 387, pág. 119). A ello se podría responder que la lesión a la dignidad humana, y en consecuencia a la individualidad genética, sólo se produce cuando una voluntad externa manipula a un ser humano para conseguir fines que son ajenos a éste. La naturaleza no lesiona derechos, de igual modo que no se infringe el derecho a la vida cuando alguien muere, sino cuando una persona niega a otra la posibilidad de vivir.
} 
Esta reductiva atención a las consecuencias que se derivan de la técnica a efectos de su valoración jurídica ha determinado que, en ocasiones, se pierda de vista un dato cierto: ambas modalidades implican una clara instrumentación de un ser humano, ya que éste es "creado" con la única finalidad de satisfacer una necesidad o un deseo ajeno, totalmente externo al propio sujeto. En este sentido, entiendo que el argumento que justifica la ilicitud ética y jurídica de la clonación no puede ser, sólo, el de que esta técnica permite la obtención de un $\underset{50}{\operatorname{ser}}$ humano con el mismo, o similar, genoma que otro, vivo o difunto. Como señala Eser ${ }^{50}$, el genoma humano, como marco de desarrollo natural de las características propias de la personalidad, debe estar protegido específicamente por el derecho, del mismo modo que lo está la integridad corporal. Esa es la razón por la que es reprobable éticamente la intervención arbitraria en el genoma de un ser humano. Pero no hay que olvidar que la identidad personal de un ser humano no se agota en su dotación genética. Hay que tener en cuenta, por un lado, que la interacción con el ambiente y la libertad individual contribuyen, asimismo, a configurar el ser individual. Por otro lado, ya he señalado anteriormente que las técnicas de clonación por transferencia de núcleos no garantizan nunca una total identidad genética. Por ello, lo cuestionable de la clonación "terapéutica" es, fundamentalmente, el hecho de que un ser humano sea producido como medio para un fin que le es totalmente ajeno y que, para la obtención de ese objetivo, se le haya impuesto una identidad genética concreta. Ello se pone especialmente de manifiesto en el supuesto de la clonación de embriones humanos con el fin de que éstos puedan servir como donantes de órganos o tejidos. De cualquier manera, también es claro que existe una instrumentalización del ser humano en los casos en los que la clonación se utiliza como técnica de reproducción asistida, con la finalidad, por ejemplo, de sustituir a un hermano fallecido.

En definitiva, la clonación de embriones humanos, con independencia de los fines que la motiven, es radicalmente contraria al principio de dignidad humana, ya que la instrumentalización afecta a la total identidad del nuevo ser. De esta manera, se convierte a miembros de la especie humana en objetos al servicio de fines que les son ajenos. Estos dejan de ser considerados, utilizando la expresión Kantiana, "un fin en si mismo" para recibir el estatuto jurídico de "cosa" u objeto.

La admisión de la clonación de embriones humanos puede incluso conducir a una comercialización del cuerpo humano y de sus órganos o tejidos. En este sentido, el Grupo Europeo de Consejeros sobre las Implicaciones Éticas de la Biotecnología (GECIEB) se ha pronunciado en contra de la clonación humana por considerar que instrumentaliza al ser humano. Su presidenta, Noëlle Lenoir, ha manifestado que tal

\footnotetext{
${ }^{50}$ ESER, A. y otros, "La Clonación Humana. Fundamentos biológicos y valoración ético-jurídica", Revista de Derecho y Genoma Humano, núm. 9, 1998, pág. 91 y ss.
} 
instrumentalización comienza en el momento en que se utiliza la técnica de la clonación de un ser humano para satisfacer una necesidad de orden personal o utilitario $^{51}$.

La Iglesia Católica también se ha pronunciado en distintas ocasiones sobre este aspecto. En una nota publicada en el órgano de la Santa Sede, "L'Osservatore Romano", bajo el título de "Una demanda imperiosa de la razón y de la humanidad", alentaba a los Estados a que no hicieran concesiones frente a la presión de las corrientes posibilistas, dispuestas a apoyar la experimentación humana de las técnicas aplicadas a la reproducción clónica animal. Por su parte, la Academia Pontificia para la Vida ha manifestado que frenar el proyecto de la clonación humana es un compromiso moral que debe traducirse también en términos culturales, sociales y legislativos.

Ciertamente, podría alegarse que la valoración de la clonación "terapéutica" dependerá del estatuto jurídico que se reconozca al embrión humano en sus distintas fases de desarrollo. De este modo, por ejemplo, si el embrión resultante de la técnica no posee más de 14 días podría admitirse su clonación. Sin embargo, es importante señalar que cualquiera que fuera el tratamiento que otorgue un concreto ordenamiento jurídico, ningún estadio del desarrollo embrionario debe quedar al margen del Derecho. Es más, todo ordenamiento jurídico debe reconocer que el embrión humano exige un tratamiento jurídico diferente al de una cosa, aunque no se le garantice igual protección jurídica que la que se reconoce a un niño recién nacido. En este sentido, por ejemplo, el Convenio del Consejo de Europa sobre los Derechos Humanos y la Biomedicina demanda una protección adecuada al embrión humano (artículo 18.1). Asimismo, sostiene que "Está prohibida la producción de embriones humanos para fines de investigación" (artículo 18.2).

\section{El derecho a la libertad de investigación}

Todo lo dicho nos conduce a sostener que una consecuencia directa del reconocimiento de la dignidad del embrión humano es la aceptación de límites al derecho a la libre investigación científica y técnica. Se trata, sin embargo, de un tema muy discutido. Ciertamente, no faltan, en la actualidad, los que consideran que, frente a la cuestión que nos ocupa, el interés que siempre debe prevalecer es la libertad de investigación. Se trata de la mentalidad que propugna que el avance de la ciencia

\footnotetext{
${ }^{51}$ Manifestaciones publicadas en Le Figaro, 5.VI.1997. Ahora bien, no parece coherente prohibir esta técnica en base a la posible instrumentalización del ser humano y no poner ninguna objeción a las técnicas de fecundación in vitro. Si existe un riesgo de cosificar al ser humano, al crearlo exclusivamente para satisfacer una determinada necesidad o deseo -como la de tener descendencia-, concurre el mismo riesgo de cosificación en la obtención de un "niño probeta". Este riesgo de considerar al nuevo ser como un medio, y no como un fin en sí mismo, también se ve incrementado, por ejemplo, con la elección de sexo a través de la fecundación in vitro.
} 
justifica, en todo caso, los medios utilizados. Como representante destacado de esta postura cabe señalar a Tristam Engelhart, el cual acepta sin reservas cualquier tipo de progreso tecnológico. Este autor sostiene, por ejemplo, en relación con la manipulación genética, que "la biotecnología nos ha otorgado el poder de convertirnos en arquitectos de nuestra propia naturaleza" ${ }^{52}$. Su posición está estrechamente conectada con lo que anteriormente hemos denominado enfoque "tecnológico" de la clonación humana. Los Presupuestos en los que se apoya este punto de vista serían, básicamente, los siguientes:

1. El desarrollo tecnológico es, en sí mismo considerado, algo neutro desde una perspectiva moral. Lo único relevante son las consecuencias que se deriven de la concreta aplicación de una técnica.

2. La clonación de seres humanos no deja de ser una mera técnica, por lo que carece de bondad o maldad intrínseca. El elemento a tener en cuenta para determinar su admisibilidad o no admisibilidad por el Derecho serán las consecuencias que de la aplicación de tal técnica se deriven para la sociedad.

A ello cabría contestar, en primer lugar, que el desarrollo tecnológico no puede, en la actualidad, considerarse como algo absolutamente neutral desde una perspectiva ética $^{53}$. La decisión humana que se inclina por el fomento de una determinada tecnología reposa sobre una antropología y una filosofía que propone esa resolución frente a otra, que plantea objetivos en una dirección y trata de responder a unas determinadas cuestiones en detrimento de otras ${ }^{54}$. Cómo señalaba Marcuse, en su crítica a Max Weber, muchas veces, en nombre de una aparente "racionalización", en realidad, a través de decisiones de pretendido carácter científico, se imponen ideologías o formas de dominio ${ }^{55}$. Este autor sostenía que:

"El concepto de razón técnica es él mismo ideología. No sólo su aplicación, sino que ya la técnica misma es dominio sobre la naturaleza y sobre los hombres, un dominio metódico, científico, calculado y calculante. No es que determinados fines e intereses de dominio sólo se avengan a la técnica a posteriori y desde fuera, sino que

${ }^{52}$ Cit. en AGIUS, E., "Terapia embrionaria. Nuestras responsabilidades para con las generaciones futuras", Concilium, 223, mayo, 1989.

${ }^{53}$ Popper sostiene que incluso algo tan aparentamente neutro como la epistemología tiene consecuencias prácticas para la ética y la política (POPPER, K., El desarrollo del conocimiento científico, Paidós, Buenos Aires, 1962, pág. 11-12)

${ }^{54}$ VID. NAREDO, J.M., "Sobre las relaciones entre ciencia, cultura y naturaleza", en Archipiélago, núm. 15, 1993, pág. 18. Así, en opinión de Quintanilla, "el desarrollo tecnológico es un asunto político, no tecnocrático" (Quintanilla, M.A., "Problemas conceptuales del desarrollo tecnológico", en El derecho al desarrollo o el desarrollo de los derechos, Universidad Complutense, Madrid, 1991, pág. 165).

Cit. en HABERMAS, J., Ciencia y técnica como "ideología", Madrid, Tecnos, 1992 (2²), pág. 54. 
entran ya en la construcción del mismo aparato técnico. La técnica es en cada caso un proyecto histórico-social; en él se proyecta lo que una sociedad y los intereses en ella dominantes tienen el propósito de hacer con los hombres y con las cosas" ${ }^{56}$.

Además, conviene tener presente que, en el ámbito específico de la investigación genética, los límites entre lo que se entiende por investigación básica y sus aplicaciones se han vuelto imprecisos. En este sentido, señala Jonas que el experimento, a diferencia de su papel delimitado en la investigación anterior, coincide con la producción originaria del objeto investigado, convirtiendo el proceso de conocimiento en acción originadora $^{57}$. En el caso de la investigación en genética humana, lo que existe entre el comienzo y el fin del experimento es la vida real de miembros de la especie humana. Esto elimina toda separación entre investigación y aplicación. Siguiendo a este autor, "el experimento es el verdadero hecho.... y el verdadero hecho, el experimento" ${ }^{58}$.

Por otro lado, no hay que olvidar que cuando la investigación se realiza sobre organismos vivos, y muy especialmente con miembros de la especie humana, hay que tener presente que, aunque el fin que se persiga sea legítimo, los medios utilizados para conseguirlo pueden convertir tal actividad en ilícita desde una perspectiva ética. Así ocurre, de un modo muy claro, en el supuesto de la clonación de seres humanos.

En nuestra opinión, es evidente que el derecho humano a la investigación y a la producción científica y técnica, consecuencia directa del reconocimiento de la dignidad humana, reviste una gran importancia y en ningún caso debe ser menospreciado. Pero ello no implica que, a su vez, pueda convertirse en una fuente de lesión de otros derechos. Como señala Peces-Barba, "ese origen no es una garantía de que un logro científico que supone tanto para la cultura de nuestro tiempo y para el futuro, no pueda a su vez, en determinados casos, convertirse en un peligro para la persona y sus derechos, por lo que genera a su vez la necesidad de nuevas protecciones y de nuevos derechos $^{\prime \prime}$.

Ciertamente, los científicos han disfrutado, durante siglos, de un alto grado de autonomía. En escasas ocasiones se han impuesto controles externos a su actividad. Sin embargo, al menos en el ámbito de la intervención en el genoma humano, parece que este principio de absoluta libertad e independencia es actualmente insostenible. Se trata de un derecho que no es absoluto, sino que posee límites. Nos encontramos frente

${ }^{56}$ MARCUSE, "Industrialisierung und Kapitalismus im Werk Max Weber", en Kultur und Gesellschaft, II, Frankfurt a. M., 1965, cit, en HABERMAS, J., Ciencia y técnica como "ideología", op. cit., pág. 55.

${ }^{57}$ JONAS, H., Técnica, medicina y ética, Paidós, Barcelona, 1977, pág. 73.

${ }^{58}$ JONAS, H., op. cit., pág. 112.

59 PECES-BARBA, G., "La libertad del hombre y el genoma", en en AAVV, El Derecho ante el Proyecto Genoma Humano, Tomo I, Fundación BBV, Madrid, 1994, pág. 202. 
a un aparente conflicto entre dos principios fundamentales: la dignidad y consiguiente exigencia de no instrumentalización del embrión humano y el derecho del científico a utilizar todas las técnicas disponibles a su alcance. $Y$ digo aparente conflicto, porque entiendo que este ajustamiento no debe presentarse como una patológica colisión de derechos, sino como una ponderación que busca encontrar la verdadera delimitación de los mismos ${ }^{60}$. Considero que la solución a esta situación pasa por el intento de reducir cada derecho a su contenido esencial que sería, al mismo tiempo, su verdadero contenido. De este modo, se puede sostener que existen otros derechos, derivados de la dignidad humana, que no sólo pueden, en determinadas circunstancias, limitar la libertad de investigación, sino que deben hacerlo. No se trata, en ningún caso, de negar el derecho, sino de reconocer que no posee un carácter absoluto ${ }^{61}$. En este sentido, en opinión de Deemer" ${ }^{62}$, el problema debe centrase, no en controlar "con medios coercitivos el derecho a la libertad de investigación", sino en "prevenir terribles abusos" $^{\prime 63}$. Ello justificará la limitación de esta libertad frente a algunas opciones científicamente posibles desde los avances de la biotecnología. Podemos recordar aquí la afirmación de la Declaración de Helsinki, en el sentido de que el interés de la ciencia o de la sociedad no debe prevalecer sobre el interés del individuo particular.

Esta posición aparece genéricamente reflejada en la Constitución Española. El artículo 20,1 apartado b), bajo el rótulo "De los derechos fundamentales y de las libertades públicas", reconoce el derecho a la producción y creación artística, científica y técnica. Pero el propio artículo 20, en su apartado 4, destaca que "Estas libertades tienen su límite en el respeto a los derechos reconocidos en este título, en los preceptos de las leyes que lo desarrollen y, especialmente, en el derecho al honor, a la intimidad a la propia imagen y a la protección de la juventud y de la infancia".

De un modo particular, se manifiesta sobre este punto la ya citada Declaración Universal sobre el Genoma y los Derechos Humanos de la UNESCO. En su artículo 6 establece que "Ningún avance científico, en el área de la biología y de la genética,

\footnotetext{
${ }^{60}$ En este sentido, quiero destacar que en mi opinión existe una tendencia actual a ampliar, indebidamente, el contenido de ciertos derechos, lo cual conduce a la proliferación de exigencias que, en realidad, no pueden ser calificadas como jurídicas. Ello, a su vez, genera un incremento de aparentes conflictos de derechos que, a largo plazo, perjudica a la misma noción de derechos fundamentales, e incluso, en mayor medida, al concepto de derechos humanos.

Sobre la "ponderación de bienes" como criterio de solución ante conflictos de normas, valores e intereses en la jurisprudencia constitucional alemana vid. LARENZ, K., Metodología de la Ciencia del Derecho, trad. RODRIGUEZ MOLINERO, Ariel, Barcelona, 1994, pág. 400 y ss.

${ }^{62}$ DEEMER, K., "Tecnología genética y hombre. Implicaciones éticas de un reto contemporáneo", en La vida humana. Origen y desarrollo. Reflexiones bioéticas de científicos y moralistas, Universidad Pontíficia de Comillas, Madrid, 1989, pág. 289.

En el mismo sentido se manifiesta Ulrich Beck (cit. en Herzog, F., "Límites del derecho penal para controlar los riesgos sociales (una perspectiva crítica ante el derecho penal de peligro)", Poder Judicial, núm. 32, 1993, pág. $80)$.
} 
puede prevalecer sobre la dignidad y los derechos de la persona humana". Por su parte, el artículo 15 dispone que los Estados tomarán las medidas apropiadas para fijar el marco del libre ejercicio de las actividades de investigación sobre el genoma, respetando los principios establecidos en la Declaración, a fin de garantizar el respeto a los derechos humanos, las libertades fundamentales y la dignidad humana, y proteger la salud pública.

\section{La clonación de embriones humanos frente al Derecho}

La experiencia demuestra que el Derecho es, habitualmente, un instrumento muy lento en reaccionar frente a los avances científico y tecnológicos ${ }^{64}$. La reflexión ética y jurídica suele aparecer cuando los efectos negativos ya se han producido, siendo precisamente éstos los que la desencadenan ${ }^{65}$. Sin embargo, en el supuesto de la clonación la tónica ha sido, en algunos aspectos, diferente. Si bien ha faltado la conveniente reflexión ética sobre el tema, la reacción jurídica se ha producido, en muchos casos, de una forma inusitadamente rápida.

Ya en el año 1988, el Parlamento Europeo elaboró un Informe sobre la experimentación e investigación en embriones humanos. Se trata del A-2-327/88, de la Comisión de Asuntos Jurídicos y derechos de los ciudadanos del Parlamento Europeo. En el se afirma que "la vida es humana desde la fecundación" (puntos 5 y 8 ), y se considera que el embrión y el feto humano deben beneficiarse en todas las circunstancias del respeto debido a la dignidad humana (punto 10). En el Informe se mantiene, asimismo, la necesidad de consensuar una definición del rango jurídico del embrión que permita garantizar la salvaguarda de su identidad genética y no permitir que sea tratado como un mero material de laboratorio. Desde este punto de vista, se afirma que "la utilización de embriones para investigaciones que nieguen su carácter humano y los sometan arbitrariamente a ciertos fines violenta la dignidad humana.... El hombre no puede ser nunca una cosa, sino que le corresponde siempre una personalidad... Y ésto debe ser también el criterio más alto en la valoración de la investigación realizada en embriones" (punto 1.5).

\footnotetext{
${ }^{64}$ VID. APARISI, A, EI Proyecto Genoma Humano: algunas reflexiones sobre sus relaciones con el Derecho, Valencia, Tirant lo blanch, 1997.

${ }^{65}$ En este sentido. Hidalgo mantiene que es peligroso experimentar primero y reflexionar después. Es, por ello, "necesario el compromiso de la comunidad internacional de sancionar normas que regulen estas prácticas (clonación humana), en virtud de que es el futuro de la humanidad lo que está en juego" (Hidalgo, S.N., "Clonación o reproducción en serie de seres humanos, ¿ una alternativa del siglo XXI?", Revista de Derecho y Genoma Humano, 1996, 4, pág. 57).
} 
En base a este Informe, el Parlamento Europeo aprobó, en 1989, una Resolución sobre los Problemas éticos y jurídicos de la manipulación genética. En su punto 41 mantiene:

"Considera que la prohibición bajo sanción es la única reacción viable a la posibilidad de producir seres humanos mediante clonación, así como con respecto a todos los experimentos que tengan como fin la clonación de seres humanos".

Sin embargo, ya hemos señalado que la reacción jurídica más contundente se produjo tras conocerse, públicamente, el experimento que condujo a la obtención de la oveja Dolly. Así, sólo un mes más tarde, el 12 de marzo de 1997, el Parlamento Europeo aprobó una Resolución sobre la clonación ${ }^{66}$. En ella se tiene en cuenta la ya referida Resolución sobre los problemas éticos y jurídicos de la ingeniería genética y de la inseminación artificial del año 1989, y una Resolución sobre clonación humana de 1993. Se afirma rotundamente que la clonación de seres humanos no puede ser admitida "ni con fines experimentales, ni en el contexto del tratamiento de la infertilidad, del diagnóstico previo a una implantación ni del trasplante de tejidos, ni con ningún otro fin, ya que constituye una grave violación de los derechos humanos fundamentales, se opone al principio de igualdad entre los seres humanos al permitir una selección eugenésica y racista de la especie humana, ofende la dignidad de la persona y requiere la experimentación con seres humanos".

En la Resolución se aboga por la adopción, a nivel internacional, de normas éticas sobre la biotecnología, y por la no financiación de ensayos sobre clonación en seres humanos. También se destaca que la tutela directa de los derechos de los individuos está por encima de cualquier interés social o de terceros. En este sentido, el eurodiputado español José Luis Valverde señaló que "las limitaciones a la libertad de investigación son un imperativo del Estado de Derecho" ${ }^{167}$.

En abril de 1997 se firmó, por representantes de 20 países, la Convención sobre Bioética, elaborada por el Consejo de Europa. La importancia del documento radica en que es el primero suscrito con carácter vinculante por la Comunidad Internacional. En su artículo 1 sostiene que las partes firmantes de la Convención protegerán la dignidad e identidad de todos los seres humanos. Ya hemos señalado que el artículo 2 defiende la primacía del ser humano sobre los intereses de la sociedad o la ciencia, y que el artículo 18.2 se opone a la creación de embriones humanos para la investigación.

A esta Convención se ha agregado un Protocolo adicional sobre la Clonación. Este sostiene, en su artículo 1, que:

${ }^{66}$ Puede consultarse en Medicina e Morale, 1997, 2, pág. 325-7.

${ }^{67}$ "El Parlamento Europeo y la OMS rechazan la clonación humana", Cuadernos de Bioética, 1997, 29, pág. 717. 
"Cualquier intervención cuyo fin sea la creación de seres humanos idénticos genéticamente a otros seres humanos, vivos o muertos, debe ser prohibida".

En nuestra opinión, esta Convención, al emplear la expresión "creación de seres humanos idénticos", debe interpretarse en el sentido de prohibir la producción, mediante esta técnica, de embriones humanos, con independencia de la finalidad a la que sean destinados tales embriones.

Ya hemos señalado, sin embargo, que la Declaración Universal sobre el Genoma Humano y los Derechos Humanos de la UNESCO no es tan clara en este punto. En su artículo 11 mantiene que:

"No deben permitirse las prácticas que sean contrarias a la dignidad humana, como la clonación con fines de reproducción de seres humanos. Se invita a los Estados y a las organizaciones internacionales competentes a que cooperen para identificar estas prácticas y a que adopten en el plano nacional e internacional las medidas que correspondan, parā asegurarse de que se respeten los principios enunciados en la presente Declaración".

He destacado que, con inusitada rapidez, muchas naciones han incorporado a su ordenamiento jurídico preceptos que prohiben la clonación humana. En este sentido, conviene reseñar que antes de 1997 la clonación ya estaba prohibida en Alemania por la Ley de protección de embriones, de 15 de diciembre de 1990. En su parágrafo 6 se establece:

"(1) Quien artificialmente produzca que se genere un embrión humano con información genética idéntica a la de otro embrión, feto, ser humano o persona muerta, será sancionado con pena privativa de libertad de hasta cinco años o con pena de multa".

Esta Ley considera, asimismo, punible la tentativa. También en Italia la obtención del primer mamífero clonado por la técnica de transferencia de núcleos produjo una reacción contundente. El Ministerio de Sanidad limitó, incluso, la realización de estos experimentos con animales.

En España, la Ley 35/1988, de 22 de noviembre, sobre Técnicas de Reproducción Asistida Humana sancionó en su artículo 20.2 como infracción administrativa muy grave "Crear seres idénticos por clonación u otros procedimientos dirigidos a la selección de la raza" (apartado k), así como "la creación de seres humanos por clonación en cualquiera de las variantes o cualquier otro procedimiento

${ }^{68} \mathrm{BOE}, 24-\mathrm{XI}-1988$ 
capaz de originar varios seres humanos idénticos" (apartado 1). Posteriormente, el Código Penal de $1995^{69}$ elevó a categoría delictiva la conducta considerada anteriormente como infracción administrativa muy grave. Así, el artículo 161.2 de nuestro texto penal castiga "la creación de seres humanos idénticos por clonación u otros procedimientos dirigidos a la selección de la raza". La pena prevista es de prisión de 1-5 años, e inhabilitación especial para empleo o cargo público, profesión u oficio de 6-10 años. Al igual que ocurre en otros países, la pena establecida es insuficiente ya que, de acuerdo con nuestro sistema penitenciario, la prisión podría ser evitada en caso de no existir antecedentes penales.

Algunos autores, haciéndose eco del debate actual en este tema, han señalado que el artículo 161.2 del Código penal español tipifica, exclusivamente, la clonación humana "reproductiva", no así la clonación de embriones con fines de obtención de células o tejidos. Sin embargo, una interpretación gramatical, sistemática y teleológica del texto legal no puede desconocer, en primer lugar, que la referencia a "ser humano" debe interpretarse, en todo caso, incluyendo el embrión humano. En segundo lugar, es fácilmente constatable que, con la inclusión de este artículo en el Código penal, el legislador pretendía prohibir toda conducta consistente en clonar embriones humanos, cualquiera que fuera el destino posterior de éstos, y con independencia de que posteriormente se implantaran o no en el útero de una mujer. Sólo así puede entenderse que el artículo 161.1 afirme que "Serán castigados con la pena de prisión de uno a cinco años e inhabilitación especial para empleo o cargo público, profesión u oficio de seis a diez años quienes fecunden óvulos humanos con cualquier fin distinto a la procreación humana".

Frente a esta línea legal, ya he señalado anteriormente que, en la actualidad, se está abriendo paso un nuevo enfoque del tema, más acorde con lo que hemos denominado al principio de nuestro trabajo "perspectiva tecnológica". Esta posición aparece claramente reflejada en el Reino Unido. En este sentido, el estudio elaborado, en enero de 1998, por la Comisión de Genética Humana y la Autoridad de Embriología y Fertilización - Organismos asesores del Gobierno británico- confirma la postura favorable a la prohibición de la clonación humana con fines de reproducción, pero no así la clonación de embriones humanos con fines terapé uticos o científicos ${ }^{70}$. De hecho, la investigación en clonación humana, siempre que se realice durante los primeros catorce días del embrión, está permitida.

\footnotetext{
${ }^{69}$ BOE 24-XI-1995.

${ }^{70}$ Vid. SAVULESCU, J., "Should we clone human beings? Cloning as a source of tissue for transplantation", Journal of Medical Ethics, 1999, 25, pág. 87-89.
} 
En los Estados Unidos de América la experimentación con embriones, aún siendo legal, posee un veto financiero. Se prohibe así la subvención pública de aquellos experimentos que conduzcan a permitir o facilitar la clonación humana, al considerarse moralmente inaceptables. Debido a la falta de legislación específica sobre clonación en este país, la Administración Federal de Alimentos y Medicamentos (FDA) asumió la responsabilidad de regular la aplicación de estas técnicas. La FDA mantiene que la clonación humana es una forma de terapia genética y, por tanto, no está, en principio, prohibida. Tan sólo se encuentra sujeta a los permisos previos por parte de las autoridades federales. Sin embargo, ya he señalado que la opinión de muchos científicos sobre este tema es favorable a la clonación con fines de investigación ${ }^{71}$.

El último documento internacional aprobado sobre este tema es la Resolución del Parlamento Europeo de septiembre del año 2000. Se puede afirmar que éste texto es el que, hasta la fecha, más rotundamente se ha manifestado sobre esta cuestión. La Resolución se aprobó como respuesta ante la presentación, y posterior aprobación, por el Parlamento inglés, de un Proyecto de reforma de la Ley sobre fertilización y embriología humana de 1990 . Como se ha señalado, la nueva regulación inglesa permite la creación de embriones humanos por clonación para obtener células madre. Frente a ello, la Resolución del Parlamento europeo señala:

"Considerando que la dignidad humana y el consiguiente valor de todo ser humano son los principales objetivos de los Estados miembros, tal como se proclama en numerosas Constituciones modernas (....) Considerando que existen formas de curar enfermedades graves sin recurrir a la clonación de embriones, como los métodos consistentes en obtener células madre a partir de personas adultas o del cordón umbilical de recién nacidos (.....) Considerando que nos encontramos ante una nueva estrategia semántica que intenta debilitar el significado moral de la clonación humana (...) Considerando que no existe ninguna diferencia entre la clonación con fines terapé uticos y la clonación con fines reproductivos, y que cualquier flexibilización de la prohibición vigente originará presiones para poder seguir desarrollando la producción y la utilización de embriones (....) Considera que los derechos humanos y el respeto de la dignidad humana y de la vida humana deben ser el objetivo constante de la actividad política legislativa (....) Considera que la clonación terapéutica, que conlleva la creación de embriones humanos con fines exclusivos de investigación, plantea un profundo dilema moral, supone traspasar de forma irreversible una frontera en las normas de investigación y es contraria a la política pública aprobada por la Unión Europea (...) Reitera su llamamiento a cada uno de los Estados miembros para que promulguen normas jurídicas vinculantes que prohiban la investigación sobre cualquier

${ }^{71}$ Sobre el debate actual acerca de la licitud ética de la investigación en Human Embryonic Stem Cells puede consultarse el número de marzo-abril del Hasting Center Report (1999, 29 (2), págs. 30-48), en el que se contienen varios trabajos sobre el tema. 
tipo de clonación de seres humanos en su territorio y establezcan sanciones penales para toda violación de las mismas (....) Pide que se haga el mayor esfuerzo posible a nivel político, legislativo, científico y económico para fomentar terapias que utilicen células madre obtenidas a partir de personas adultas(...)".

\section{Conclusión}

En resumen, podemos afirmar que la clonación de embriones humanos presenta a la humanidad dilemas de un profundo calado antropológico, ético y jurídico. Se trata de desafíos a la misma idea de dignidad humana que, a comienzos del siglo XXI, parece ser el único antídoto ante un economicismo y un utilitarismo que sólo atiende al valor de mercado. El problema, en definitiva, es que, aunque somos capaces de conseguir lo inimaginable, no sabemos bien quienes somos ni hacia donde vamos. A menos que consigamos responder a estas cuestiones, el hombre de la era de la biotecnología está condenado a ser su criatura, cuando no su esclavo ${ }^{72}$. Aunque es necesario poner límites, aprobar normas jurídicas con el fin de evitar o disminuir daños causados, lo que importa es comprender la verdadera naturaleza de lo que está ocurriendo y el lugar que debe ocupar el ser humano, individualmente considerado, en todo este vertiginoso proceso. En palabras de Herranz ${ }^{73}$, puede mantenerse que, en buena medida, el destino de la humanidad vendrá fuertemente determinado por la respuesta a la pregunta de sí el embrión humano es una cosa, un ser humano, o una entidad intermedia todavía por definir. Lo que estamos debatiendo es, en suma, la misma noción de ser humano y el significado de su dignidad. El respeto a esta dignidad genera que, en el ámbito científico, no todo lo que se puede hacer se deba hacer.

\footnotetext{
${ }^{72}$ Vid. KASS, L.R., "The Moral Meaning of Genetic Technology", Commentary, septiembre, 1999.

${ }^{73}$ HERRANZ, G., "Etica de las intervenciones sobre el embrión preimplantado", en Anuario Filosófico, XXVIII, $1994,127-28$
} 